\section{BMJ Open Respiratory Research}

\title{
Sputum colour can identify patients with neutrophilic inflammation in asthma
}

\author{
Kavita Pabreja, ${ }^{1}$ Peter Gibson, ${ }^{1}$ Alyssa J Lochrin, ${ }^{2}$ Lisa Wood, ${ }^{2}$ Katherine J Baines, ${ }^{2}$ \\ Jodie L Simpson ${ }^{2}$
}

To cite: Pabreja K, Gibson P, Lochrin AJ, et al. Sputum colour can identify patients with neutrophilic inflammation in asthma. BMJ Open Resp Res 2017;4:e000236. doi:10.1136/ bmjresp-2017-000236

- Additional material is published online only. To view please visit the journal online (http://dx.doi.org/10.1136/ bmjresp-2017-000236).

Received 2 August 2017 Revised 19 September 2017

\section{(a) CrossMark}

${ }^{1}$ Priority Research Centre for Healthy Lungs, School of Medicine and Public Health, Hunter Medical Research Institute, The University of Newcastle, Newcastle, New South Wales, Australia ${ }^{2}$ Priority Research Centre for Healthy Lungs, School of Biomedical Sciences and Pharmacy, Hunter Medical Research Institute, The University of Newcastle, Newcastle, New South Wales, Australia

Correspondence to Professor Jodie L Simpson; jodie.simpson@newcastle. edu.au

\section{ABSTRACT}

Introduction Sputum colour is associated with neutrophilic inflammation in chronic bronchitis and chronic obstructive pulmonary disease (COPD). Neutrophilia and sputum expectoration is notable in asthma, but whether sputum colour is associated with and predicts the presence of neutrophilic inflammation in asthma is unknown. The objective of the study is to assess the ability of sputum colour in distinguishing asthma inflammatory phenotypes.

Methods Induced sputum samples collected from 271 adults with stable asthma were retrospectively assessed. Sputum colour was determined using the BronkoTest sputum colour chart and correlated to differential cell counts and CXCL-8 concentration. Neutrophilic inflammation was defined as an age-corrected sputum neutrophil proportion ( $\geq 61.6 \%$ for age $20-40$ years; $\geq 63.2 \%$ for age $40-60$ and $\geq 67.2 \%$ for age $>60$ years), whereas neutrophilic bronchitis (NB) was defined as high total cell count $\left(\geq 5.1 \times 10^{6}\right.$ cells $\left./ \mathrm{mL}\right)$ plus an increased age-corrected neutrophil proportion. The optimal cut-off for sputum colour to predict neutrophilic inflammation and NB was determined using receiver operator characteristic curve analysis.

Results A sputum colour score of $\geq 3$ represented and predicted neutrophilic inflammation with modest accuracy (area under the curve (AUC) $=0.64 ; p<0.001$, specificity $=78.4 \%$, sensitivity $=49.2 \%$ ). Participants with a sputum colour score of $\geq 3$ had significantly $(p<0.05)$ higher CXCL-8, total cells and neutrophil number and proportion. Sputum colour score was also positively correlated with these factors. Sputum colour score $\geq 3$ predicted NB with reasonably good accuracy $(A \cup C=0.79$, $p<0.001$, specificity $=79.3 \%$, sensitivity $=70.7 \%$ ). Conclusions Visual gradation of sputum colour in asthma relates to high total cell count and neutrophilic inflammation. Assessment of sputum colour can identify adults with asthma who are likely to have NB without the need for sputum processing and differential cell count, which may facilitate asthma management.

\section{INTRODUCTION}

Asthma is a chronic airway disease characterised by episodic symptoms, variable airflow obstruction and inflammation. ${ }^{2}$ Airway inflammation in asthma is complex. While differential cell counts in induced sputum and endobronchial biopsies can successfully

\section{key message}

Sputum colour may assist with the identification of neutrophilic inflammation and neutrophilic bronchitis and assist with clinical decision making to assess the presence of neutrophilic inflammation and bacteria in asthma.

discriminate and identify inflammation subtypes, ${ }^{3}{ }^{4}$ these tools have limitations of being non-automated and labour-intensive. Thus, there is a need to identify simpler tools and surrogate clinical markers that could distinguish inflammation subtypes in asthma.

Blood eosinophil count and fractional exhaled nitric oxide concentration are useful tools to predict the presence of eosinophilic inflammation. ${ }^{56}$ However, these measures are not sufficiently sensitive and specific to predict the presence of neutrophilic inflammation, ${ }^{78}$ which is associated with a poor response to corticosteroid therapy ${ }^{9}{ }^{10}$ and may require alternative anti-inflammatory or antimicrobial pharmacotherapy. One alternative may be the BronkoTest sputum colour chart which uses an observer-based reference card comprising a 5-point colour scale. The detection of the green colour comes from myeloperoxidase, which is present in the azurophil granules of airway neutrophils. ${ }^{11}{ }^{12}$ Green sputum has also been reported in eosinophil-rich sputum samples; therefore, it is necessary to assess the performance of the BronkoTest in asthma.

The assessment of sputum colour in other neutrophilic airway diseases such as non-cystic bronchiectasis, ${ }^{13}{ }^{14}$ chronic bronchitis ${ }^{15}{ }^{16}$ and in both stable and acute exacerbations of chronic obstructive pulmonary disease $(\mathrm{COPD})^{1718}$ has been associated with the presence of pathogenic microbes, ${ }^{16} 19$ airway inflammation, proteolytic damage. ${ }^{14}$ So far, there has been only one study in asthma which demonstrated a positive correlation between sputum colour and neutrophilia. ${ }^{20}$ 
However, this study did not use any colour scoring card to rank sputum colour and sample was characterised as mucoid if it was clear, white or grey; mucopurulent if uncertainty existed about whether it was mucoid or tinged yellow; and purulent if it was definitely yellow or green. We extend previous findings by examining the capacity of sputum colour score chart to identify neutrophilic inflammation in asthma and determine its relationship with underlying inflammatory biochemical markers and bacterial presence.

Moreover, two approaches defining neutrophilic inflammation associated with asthma are reported. Both methodologies employ sputum differential cell counts to identify the inflammation subtypes. ${ }^{421}$ One uses high neutrophil cell proportion ${ }^{422}$ described as neutrophilic inflammation, whereas the alternative considers an increased total cell number together with an increased neutrophil proportion ${ }^{21}$ defined as neutrophilic bronchitis (NB), thereby identifying a subset of clinically stable patients that are unresponsive to the prescribed treatments. ${ }^{21} 23$

In this study we sought to test the hypothesis that sputum colour score would be able to (1) distinguish between asthma with neutrophilic and non-neutrophilic inflammation as well as (2) predict the presence of NB in asthma. To test this hypothesis, we used the BronkoTest sputum colour chart to record sputum colour collected from adults with asthma participating in clinical studies.

\section{METHODS}

\section{Study design}

This was a retrospective cross-sectional analysis of baseline data pooled from multiple studies where participants with asthma were evaluated, ${ }^{724}$ including assessment of sputum cell count. Demographic details, asthma symptoms and therapy were recorded. After recruitment, the individuals were subjected to clinical assessment, allergy skin test, spirometry and sputum induction to obtain induced sputum for subsequent cytological, biochemical and microbiological analyses. Sputum colour was recorded at the time of sputum processing using the BronkoTest sputum colour chart. Measurements were carried out by observers blinded to other results.

Each participant provided a written informed consent prior to the study.

\section{Participants}

Adults with stable asthma who underwent a sputum induction and produced an adequate sputum sample determined by a cell viability of $>40 \%$ and squamous cell count of $<50 \%$ were eligible for analysis. Participants had a primary care physician diagnosis of asthma, current episodic respiratory symptoms in the preceding 12 months and evidence of variable airflow obstruction, ${ }^{25}$ which was assessed by either airway hyper-responsiveness or bronchodilator response or diurnal variation of peak expiratory flow. If the participants undertook more than one study, data from the most recent visit were included.

Patients were not eligible to participate if they were current smokers, had a current or recent chest infection or an altered asthma therapy in the preceding 4 weeks, and/or had a primary diagnosis of an airway disease other than asthma. Ex-smokers were included where smoking was ceased $>6$ months prior to the study visit.

\section{Definitions}

- Neutrophilic inflammation was defined as participants with a sputum age-corrected neutrophil proportion $\geq 61.61 \%$ (age $20-40$ years), $\geq 63.20 \%$ (age $40-60$ years) and $\geq 67.2 \%$ (age $>60$ years). ${ }^{22}$

- NB was defined as participants with both an increased number of sputum cells (total cell count $\geq 5.1 \times 10^{6}$ cells $/ \mathrm{mL}$ ) together with an elevated age-corrected neutrophil proportion (as per above definition). ${ }^{21}$

\section{Spirometry and sputum induction}

Spirometry (CPFS/D USB Spirometer, BreezeSuite V.7.1, MGC Diagnostics, Saint Paul, Minnesota, USA) and combined bronchial provocation testing and/or sputum induction with hypertonic saline were performed as previously described. ${ }^{2}$ Briefly, participants inhaled saline $(4.5 \% \mathrm{w} / \mathrm{v})$ for doubling time periods $(30 \mathrm{~s}, 1 \mathrm{~min}, 2 \mathrm{~min}$, $4 \mathrm{~min}$ ) from a nebuliser (DeVilbiss ultrasonic nebuliser, Sunrise Medical Limited, Stourbridge, UK). The test was stopped when either the forced expiratory volume in $1 \mathrm{~s}\left(\mathrm{FEV}_{1}\right)$ fell by $>20 \%$ or the nebulisation time of 15.5 cumulative minutes had elapsed. ${ }^{2}$

\section{Sputum processing and analysis}

Briefly, the sputum volume and macroscopic characteristics were recorded and opaque, mucocellular clumps were dispersed with dithiothreitol (Sputolysin, Merck Millipore, Darmstadt, Germany) and filtered before the total leucocyte count and viability were assessed. Cell viability was assessed using the trypan blue exclusion method.

Supernatant was aspirated for storage at $-80^{\circ} \mathrm{C}$ and cytospins were prepared and stained using May-Grünwald Giemsa prior to a differential cell count of 400 non-squamous cells. ${ }^{26}$ CXCL-8 concentration in sputum supernatant was measured by ELISA (R\&D Systems Minneapolis, Minnesota, USA) as previously described ${ }^{27}$ in subset of samples where supernatant volume was sufficient.

\section{Sputum culture}

Briefly, serial dilutions of homogenised sputum samples were prepared in phosphate buffered saline and used to inoculate chocolate bacitracin and blood agar plates that were examined for bacterial growth after 24 and 48 hours by trained microbiologists at Pathology North, John Hunter Hospital. ${ }^{28}$ 


\section{Sputum colour assessment}

Sputum colour was assessed by laboratory staff using a 5-point sputum colour chart (BronkoTest; Heredilab Inc, Salt Lake City, Utah, USA) as soon as the sample was received in the lab and prior to sputum processing. The presence of opaque clumps in the sputum sample was also considered while recording sputum colour. Colours 1 and 2 were regarded as mucoid, whereas colours 3-5 represented purulent sputum. ${ }^{29}$

\section{Analysis}

Data were analysed using Stata V.14 (Stata Corporation, College Station, Texas, USA). Results are reported as mean (SD), median (quartile (q) q1, q3) unless stated. Analysis was performed using the two-sample Wilcoxon rank sum test or Kruskal-Wallis test for more than two groups and Fisher exact test for categorical data. Results were reported as significant when $\mathrm{p}<0.05$. The performance characteristic of sputum colour was examined by receiver operating characteristic (ROC) curves and area under the curve (AUC). ROC analysis determined the sputum colour score cut-off which best defined neutrophilic inflammation based on the BronkoTest sputum colour chart.

\section{RESULTS}

\section{Clinical characteristics of asthma population}

Participants had a mean age of 56.2 years, were predominantly atopic $(73.3 \%)$ with moderate airway obstruction (mean (SD) $\mathrm{FEV}_{1} \%$ predicted, 79.0 (19.0)). More than one-third of participants had smoked in the past with a median pack year history of 7.5 and the majority of participants $(77.1 \%)$ were prescribed inhaled corticosteroids. Sputum culture was performed where sufficient quantity of sample was available following cytological assessments. Microbiological examination was undertaken on 139 (51.3\%) samples with 21 (15.1\%) confirmed positive for bacterial pathogens (see online supplementary file table 1 ).
(A)

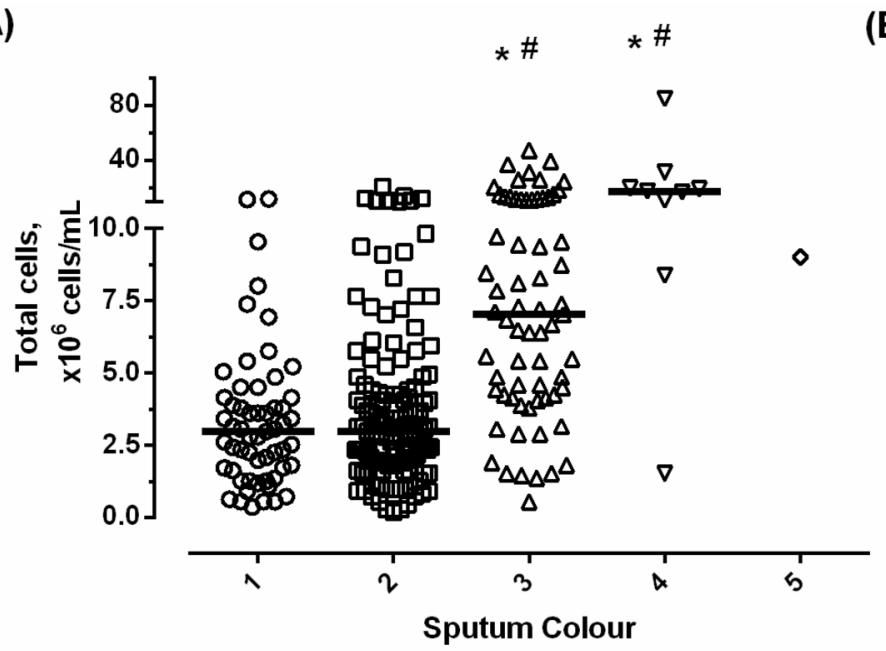

(C)

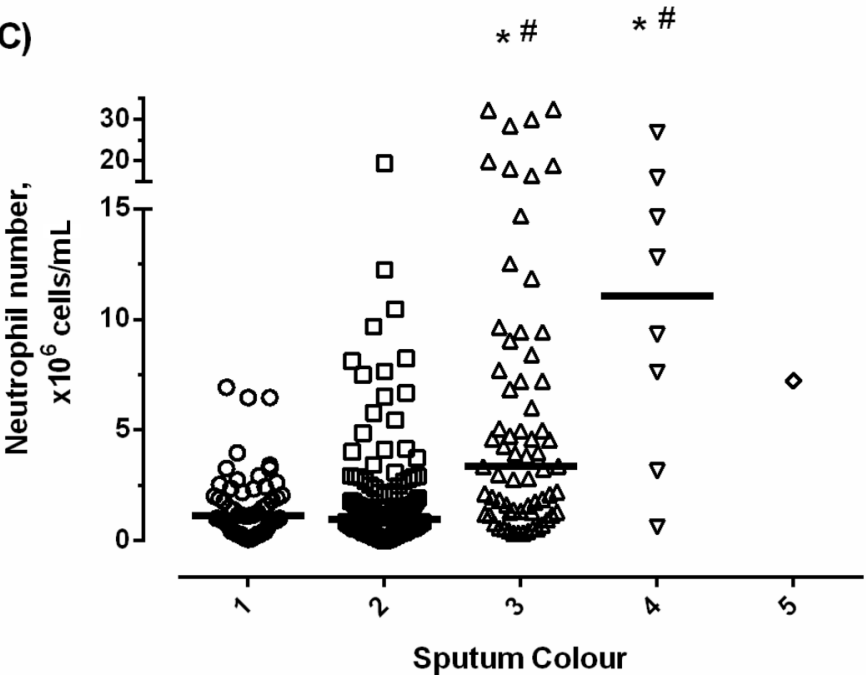

(B)

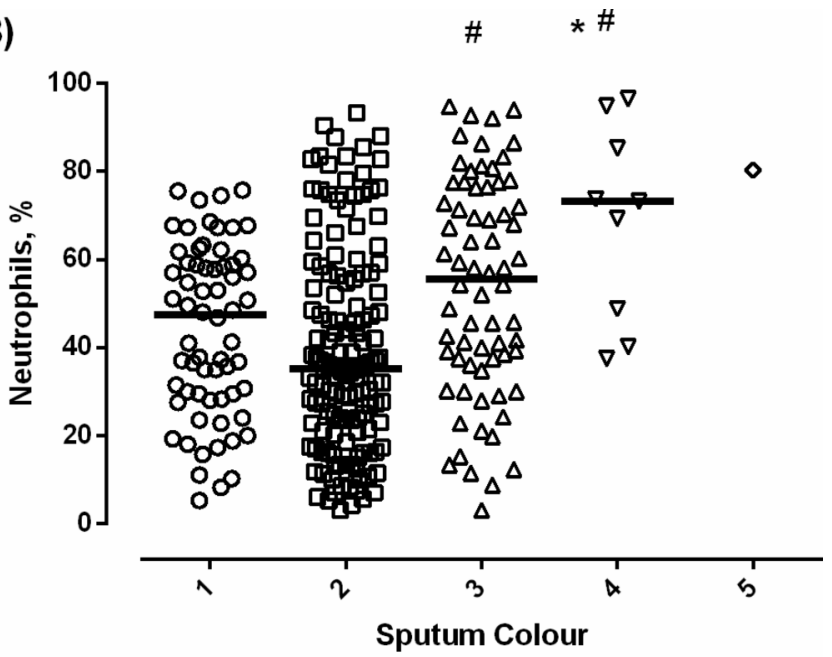

(D)

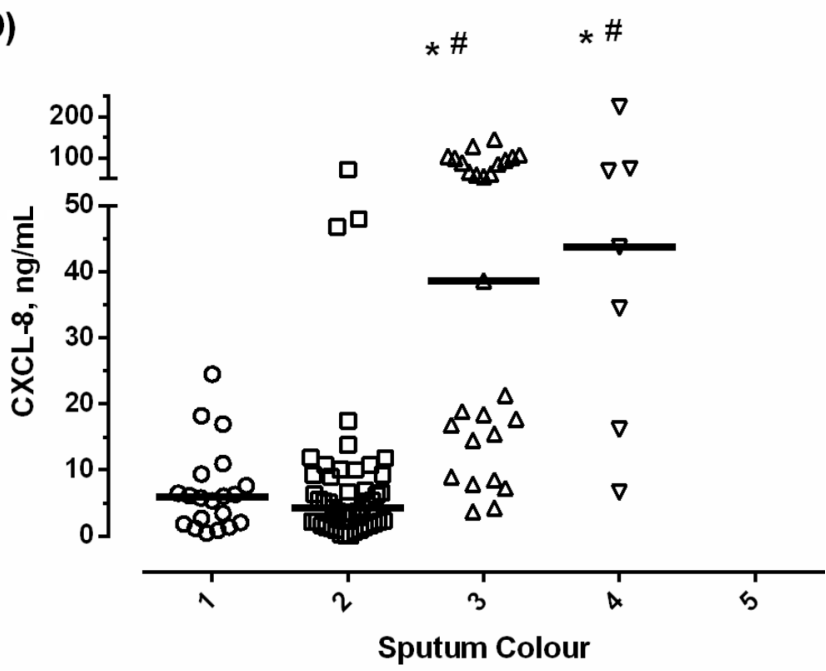

Figure 1 Association of sputum colour score with (A) total cell counts; (B) neutrophil proportion; (C) neutrophil number and (D) CXCL-8 concentration. Horizontal bars represent median values; $p<0.001$ (Kruskal-Wallis and Dunn's multiple comparison test); $\mathrm{p}<0.05$ versus *sputum colour score 1 and "sputum colour score 2. 
Table 1 Comparison of participants with neutrophilic and non-neutrophilic sputum samples

\begin{tabular}{|c|c|c|c|}
\hline & Neutrophilic inflammation & No neutrophilic inflamn & $\mathrm{p}$ Value \\
\hline Number of subjects & 67 & 204 & \\
\hline Age (years), mean (range) & $59.9(32.5-78.9)$ & $55.0(18.9-85.9)$ & 0.063 \\
\hline Sex, man, $n(\%)$ & $34(50.7)$ & $83(40.7)$ & 0.158 \\
\hline Atopic, n (\%) & 43 (66.1), n=65 & 149 (75.6), $n=197$ & 0.147 \\
\hline Ex-smoker, n (\%) & $27(40.3)$ & $73(35.8)$ & 0.560 \\
\hline Pack years, median $(q 1, q 3)$ & $7.5(1.5,25.0) n=27$ & $7.7(0.7,26.0), n=70$ & 0.871 \\
\hline $\mathrm{FEV}_{1} \%$ predicted, mean (SD) & $72.6(17.5)$ & $81.1(19.0)$ & 0.001 \\
\hline $\mathrm{FEV}_{1} / \mathrm{FVC}(\%)$, mean (SD) & $68.1(10.6)$ & $70.9(10.5)$ & 0.075 \\
\hline ICS dose* $(\mu \mathrm{g} /$ day), median (q1,q3) & $1000(800,2000), n=53$ & $1000(570,2000), n=156$ & 0.639 \\
\hline \multicolumn{4}{|l|}{ Sputum cell counts, median (q1,q3) } \\
\hline Total cell number $\left(\times 10^{1}\right.$ cells $\left./ \mathrm{mL}\right)$ & $8.6(3.6,13.5), n=66$ & $3.1(1.9,4.9), \mathrm{n}=202$ & $<0.001$ \\
\hline Viability (\%) & $90.2(83.5,95.8)$ & $77.1(63.8,86.4)$ & $<0.001$ \\
\hline Neutrophils (\%) & $76.0(70.2,83.2)$ & $34.9(21.2,47.0)$ & $<0.001$ \\
\hline Neutrophil† $\left(\times 10^{1} / \mathrm{mL}\right)$ & $623.5(286.2,1186.4)$ & $95.0(42.6,182.7)$ & $<0.001$ \\
\hline Eosinophils (\%) & $1.2(0.5,2.5)$ & $1.5(0.5,7.9)$ & 0.069 \\
\hline Eosinophil† $\left(\times 10^{2} / \mathrm{mL}\right)$ & $6.7(3.6,20.9)$ & $4.5(0.9,28.2)$ & 0.137 \\
\hline Macrophages (\%) & $17.7(13.2,23.0)$ & $55.7(41.0,66.9)$ & $<0.001$ \\
\hline Macrophage $\left(\times 10^{4} / \mathrm{mL}\right)$ & $124.5(59.3,241.6)$ & $162.6(96.0,268.5)$ & 0.057 \\
\hline Lymphocytes (\%) & $0.5(0.0,1.2)$ & $0.7(0.2,1.5)$ & 0.178 \\
\hline Lymphocyte† (×104/mL) & $3.4(0.0,9.2)$ & $1.9(0.2,4.9)$ & 0.039 \\
\hline Columnar epithelial cells (\%) & $0.7(0.2,1.7)$ & $1.7(0.5,5.2)$ & $<0.001$ \\
\hline Columnar epithelial cells $\dagger\left(\times 10^{4} / \mathrm{mL}\right)$ & $4.4(0.8,8.5)$ & $4.4(1.0,12.1)$ & 0.576 \\
\hline CXCL-8 (ng/mL), median (q1, q3) & $17.9(6.3,70.0), n=28$ & $6.1(2.2,11.9), n=75$ & $<0.001$ \\
\hline Sputum culture performed, n (\%) & $36(53.7)$ & $103(50.5)$ & 0.674 \\
\hline Positive culture, n (\%) & $13(36.1)$ & $8(7.8)$ & $<0.001$ \\
\hline Purulent sputum, n (\%) & $33(49.2)$ & $44(21.6)$ & $<0.001$ \\
\hline \multicolumn{4}{|l|}{ Sputum colour, n (\%) } \\
\hline 1 & $11(16.4)$ & $47(23.0)$ & 0.304 \\
\hline 2 & $23(34.3)$ & $113(55.4)$ & 0.003 \\
\hline 3 & $27(40.3)$ & $41(20.1)$ & 0.002 \\
\hline 4 & $5(7.5)$ & $3(1.5)$ & 0.024 \\
\hline 5 & $1(1.5)$ & $0(0.0)$ & 0.247 \\
\hline
\end{tabular}

*ICS dose is calculated as beclomethasone equivalent dose, where $1 \mu \mathrm{g}$ of beclomethasone $=1 \mu \mathrm{g}$ budesonide $=0.5 \mu \mathrm{g}$ fluticasone. †Cell numbers represent data from 66 and 202 patients with neutrophilic and no neutrophilic inflammation subgroups, respectively. $\mathrm{FEV}_{1}$, forced expiratory volume in $1 \mathrm{~s}$; FVC, forced vital capacity; ICS, inhaled corticosteroids; n, number of participants; q, quartile.

\section{Sputum colour in asthma}

A higher sputum colour score of $\geq 3$ demonstrated significantly higher total cell counts (figure 1A), neutrophil proportion (figure 1B), neutrophil number (figure 1C) and concentration of CXCL-8 (figure 1D), when compared with participants having a sputum colour score $<3$. Also, sputum colour score was significantly higher in samples detected positive for bacterial pathogens when compared with samples observed negative for microbial presence (Spearman's rho $=0.339 ; \mathrm{p}<0.001 ; \mathrm{n}=139$ ).

Neutrophilic inflammation was identified in $67(24.7 \%)$ participants (table 1). Participants with neutrophilic inflammation were clinically similar with respect to age, atopy, inhaled corticosteroid dose and smoking history. Patients with neutrophilic inflammation in asthma had significantly increased airway obstruction $\left(\mathrm{FEV}_{1} \%\right.$ predicted), total number of cells, neutrophil number and proportion, CXCL-8 concentration together with greater proportion of positive cultures for bacterial pathogens and a higher sputum colour score when compared with non-neutrophilic asthma $(\mathrm{p}<0.001$; table 1$)$.

ROC curve analysis was performed to assess the performance of sputum colour to predict the participants with neutrophilic inflammation based on neutrophil 
(A)

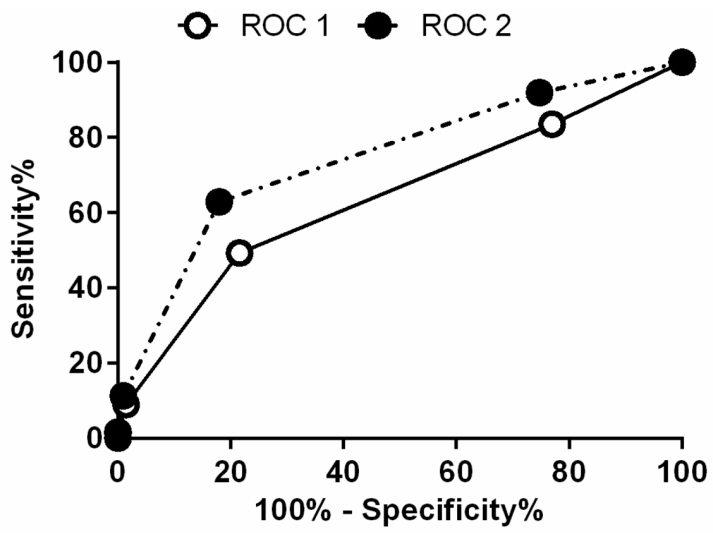

\begin{tabular}{|l|c|c|c|c|}
\hline \multicolumn{1}{|c|}{ ROC curve } & $\begin{array}{c}\text { Area under } \\
\text { the curve }\end{array}$ & $\mathbf{9 5 \%} \mathrm{Cl}$ & p-value & $\mathbf{n}$ \\
\hline $\begin{array}{l}\text { ROC 1: based on neutrophil } \\
\text { proportion }\end{array}$ & 0.64 & 0.56 to 0.72 & 0.0006 & 271 \\
\hline $\begin{array}{l}\text { ROC 2: based on neutrophil } \\
\text { number }\end{array}$ & 0.74 & 0.67 to 0.82 & $<0.0001$ & 268 \\
\hline
\end{tabular}

(B)

\begin{tabular}{|c|c|c|c|c|}
\hline $\begin{array}{c}\text { Sputum colour } \\
\text { cut point }\end{array}$ & Sensitivity, \% & Specificity, \% & LR+ & LR- \\
\hline \multicolumn{5}{|l|}{ ROC curve 1: based on neutrophil proportion } \\
\hline$\geq \mathbf{1}$ & 100.00 & 0.00 & 1.000 & \\
\hline$\geq 2$ & 84.58 & 23.04 & 1.086 & 0.713 \\
\hline$\geq 3$ & 49.25 & 78.43 & 2.284 & 0.647 \\
\hline$\geq 4$ & 8.96 & 98.53 & 6.090 & 0.924 \\
\hline$\geq 5$ & 1.49 & 100.00 & & 0.985 \\
\hline \multicolumn{5}{|l|}{} \\
\hline$\geq \mathbf{1}$ & 100.00 & 0.00 & 1.000 & \\
\hline$\geq \mathbf{2}$ & 91.94 & 25.24 & 1.230 & 0.319 \\
\hline$\geq 3$ & 62.90 & 82.04 & 3.502 & 0.452 \\
\hline$\geq 4$ & 11.29 & 99.03 & 11.629 & 0.896 \\
\hline$\geq \mathbf{5}$ & 1.61 & 100.00 & & 0.984 \\
\hline
\end{tabular}

Figure 2 Accuracy of sputum colour in predicting neutrophilic inflammation. (A) ROC curve showing the ability of sputum colour to predict the presence of neutrophilic asthma. (B) Sensitivity, specificity, positive and negative likelihood ratio (LR+ and LR-, respectively) tabulated for each sputum colour group cut point based on neutrophil proportion (ROC 1) and absolute neutrophil count (ROC 2). LR-, negative likelihood ratio; LR+, positive likelihood ratio; n, number of participants; ROC, receiver operator characteristic.

proportion (ROC 1) and neutrophil number (ROC 2; figure 2A). AUC was highest for neutrophil number (AUC 0.74, $\mathrm{p}<0.001$ ). Neutrophilic inflammation using either proportion or number identified an optimal cut-off score of $\geq 3$ for sputum colour to discriminate between neutrophilic and non-neutrophilic inflammation in asthma (figure 2B). Sputum colour could not predict the presence of eosinophilic asthma (AUC 0.52; $\mathrm{p}=0.563$ ) but was able to discriminate a positive bacterial culture indicating bacterial presence with a reasonably good accuracy (AUC 0.755; $\mathrm{p}<0.001 \mathrm{n}=139$; see online supplementary file figure 1 ).

\section{NB in asthma}

A total cell count and neutrophil proportion was available from 268 participants with 43 (16.0\%) categorised as NB (table 2). Those with NB were older, with increased airway obstruction $\left(\mathrm{FEV}_{1} \%\right.$ predicted), increased total and inflammatory cell counts and CXCL-8 concentration (table 2). ROC analysis revealed an AUC of 0.79, $\mathrm{p}<0.001$ (figure $3 \mathrm{~A}$ ) and sputum colour score cut-off of $\geq 3$ that could effectively discriminate between asthma with and without NB with a reasonably good accuracy besides a sensitivity of $70.73 \%$ and specificity of $79.30 \%$ (figure $3 \mathrm{~B}$ ). 


\begin{tabular}{|c|c|c|c|}
\hline & NB & No NB & p Value \\
\hline Number of subjects & 43 & 225 & \\
\hline Age (years), mean (range) & $61.0(32.5,78.9)$ & $55.3(18.9,85.9)$ & 0.028 \\
\hline Sex, man, $n(\%)$ & $23(53.5)$ & $94(41.8)$ & 0.181 \\
\hline Atopic, n (\%) & 30 (71.4), $n=42$ & 159 (73.3), $n=217$ & 0.850 \\
\hline Ex-smoker, n (\%) & $18(41.9)$ & $80(35.6)$ & 0.490 \\
\hline Pack years, median $(q 1, q 3)$ & $6.2(1.8,25.0), \mathrm{n}=18$ & $8.0(1.0,26.0), n=77$ & 0.961 \\
\hline $\mathrm{FEV}_{1} \%$ predicted, mean (SD) & $66.7(14.4)$ & $81.3(18.9)$ & $<0.001$ \\
\hline $\mathrm{FEV}_{1} / \mathrm{FVC}(\%)$, mean (SD) & $65.7(10.1)$ & $71.0(10.4)$ & 0.001 \\
\hline ICS dose* ( $\mu \mathrm{g} /$ day), median (q1,q3) & $1000(800,2000), n=35$ & $1000(800,2000), n=171$ & 0.705 \\
\hline \multicolumn{4}{|l|}{ Sputum cell counts, median ( $q 1, q 3)$} \\
\hline Total cell number $\left(\times 10^{6}\right.$ cells $\left./ \mathrm{mL}\right)$ & $11.2(9.4,19.8)$ & $3.1(1.8,4.5)$ & $<0.001$ \\
\hline Viability (\%) & $92.0(87.1,96.3)$ & $77.9(66.7,87.1)$ & $<0.001$ \\
\hline Neutrophils (\%) & $77.5(70.2,86.2)$ & $36.5(23.5,53.0)$ & $<0.001$ \\
\hline Neutrophil $\left(\times 10^{4} / \mathrm{mL}\right)$ & $942.6(666.6,1586.9)$ & $103.2(47.4,201.3)$ & $<0.001$ \\
\hline Eosinophils (\%) & $1.0(0.5,3.0)$ & $1.5(0.5,6.7)$ & 0.305 \\
\hline Eosinophil $\left(\times 10^{4} / \mathrm{mL}\right)$ & $13.4(6.1,46.6)$ & $4.0(0.9,19.3)$ & $<0.001$ \\
\hline Macrophages (\%) & $17.0(10.7,23.0)$ & $52.0(36.2,65.2)$ & $<0.001$ \\
\hline Macrophage $\left(\times 10^{4} / \mathrm{mL}\right)$ & $218.7(150.0,302.9)$ & $145.8(82.6,243.8)$ & 0.004 \\
\hline Lymphocytes (\%) & $0.5(0.2,1.0)$ & $0.7(0.2,1.5)$ & 0.187 \\
\hline Lymphocyte $\left(\times 10^{4} / \mathrm{mL}\right)$ & $5.5(1.8,16.5)$ & $1.8(0.1,4.7)$ & $<0.001$ \\
\hline Columnar epithelial cells (\%) & $0.2(0.0,1.0)$ & $1.7(0.5,4.9), n=224$ & $<0.001$ \\
\hline Columnar epithelial cells $\left(\times 10^{4} / \mathrm{mL}\right)$ & $4.7(0,12.1)$ & $4.3(1.0,11.9) n=224$ & 0.943 \\
\hline CXCL-8 (ng/mL), median (q1, q3) & $46.8(16.8,99.8), n=19$ & $6.1(2.3,11.4), n=84$ & $<0.001$ \\
\hline Sputum culture performed, $\mathrm{n}(\%)$ & $21(48.8)$ & $116(51.6)$ & 0.868 \\
\hline Positive culture, $n(\%)$ & $11(52.4)$ & $10(8.6)$ & $<0.001$ \\
\hline Purulent sputum, n (\%) & $30(69.8)$ & $46(20.4)$ & $<0.001$ \\
\hline \multicolumn{4}{|l|}{ Sputum colour, n (\%) } \\
\hline 1 & $1(2.3)$ & $56(24.9)$ & $<0.001$ \\
\hline 2 & $12(27.9)$ & $123(54.7)$ & 0.001 \\
\hline 3 & $24(55.8)$ & $43(19.1)$ & $<0.001$ \\
\hline 4 & $5(11.6)$ & $3(1.3)$ & 0.003 \\
\hline 5 & $1(2.3)$ & $0(0.0)$ & 0.160 \\
\hline
\end{tabular}

${ }^{*}$ ICS dose is calculated as beclomethasone equivalent dose, where $1 \mu \mathrm{g}$ of beclomethasone $=1 \mu \mathrm{g}$ budesonide $=0.5 \mu \mathrm{g}$ fluticasone. $\mathrm{FEV}_{1}$, forced expiratory volume in $1 \mathrm{~s}$; FVC, forced vital capacity; ICS, inhaled corticosteroids; $n$, number of participants; NB, neutrophilic bronchitis; q, quartile.

\section{DISCUSSION}

In this study we assessed induced sputum samples from patients with established stable asthma to examine the relationship between sputum colour and components of airway inflammation (total cell number, neutrophil number and proportion and CXCL-8) using BronkoTest sputum colour chart. In patients with stable asthma, a sputum sample colour score of $\geq 3$ correlated positively with neutrophilic inflammation and could predict the presence of neutrophilic inflammation with modest accuracy and NB with reasonably good accuracy. The fundamental principle guiding the concept is the distinctive deep green colour attributed to the presence of the green haem-containing protein, myeloperoxidase, within the azurophil granules of neutrophils and proinflammatory monocytes. ${ }^{30} 31$ Thus, clear/white sputum indicates the absence of significant number of neutrophils, whereas pale yellow/ green and green sputum respectively depicts modest and large numbers of neutrophils. Importantly, the BronkoTest sputum colour chart was unable to predict the presence of eosinophilic inflammation.

Sputum assessment is limited by the requirement of both sputum induction and the processing of the sputum sample and undertaking a differential cell counting. 
(A)

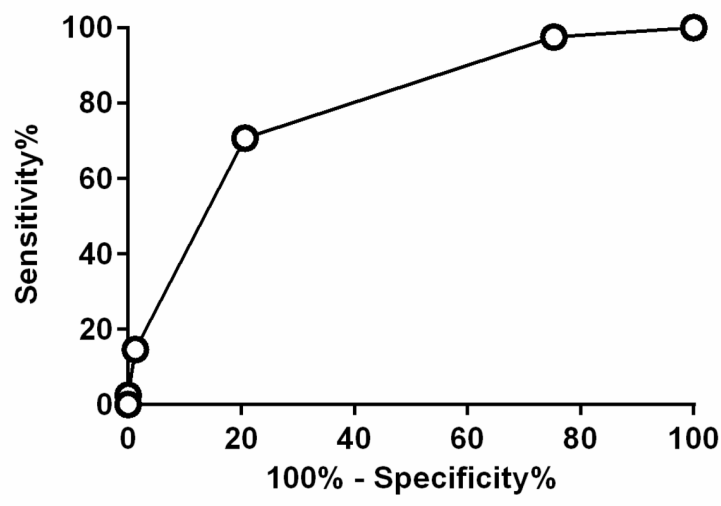

\begin{tabular}{|l|c|c|c|c|}
\hline & Area under the curve & $95 \% \mathrm{Cl}$ & p-value & $\mathbf{n}$ \\
\hline ROC curve & 0.79 & 0.71 to 0.86 & $<0.0001$ & 268 \\
\hline
\end{tabular}

(B)

\begin{tabular}{|c|c|c|c|c|}
\hline $\begin{array}{c}\text { Sputum colour } \\
\text { cut point }\end{array}$ & Sensitivity, \% & Specificity, \% & LR+ & LR- \\
\hline$\geq \mathbf{1}$ & 100.00 & 0 & 1.000 & \\
\hline$\geq \mathbf{2}$ & 97.56 & 24.67 & 1.295 & 0.099 \\
\hline$\geq \mathbf{3}$ & 70.73 & 79.30 & 3.416 & 0.369 \\
\hline$\geq \mathbf{4}$ & 14.63 & 98.68 & 11.073 & 0.865 \\
\hline $\mathbf{2 5}$ & 2.44 & 100.00 & & 0.976 \\
\hline
\end{tabular}

Figure 3 Accuracy of sputum colour in predicting NB. (A) ROC curve showing the ability of sputum colour score to predict NB. (B) Sensitivity, specificity, positive and negative likelihood ratio (LR+ and LR-, respectively) tabulated for each sputum colour group cut point to identify participants with NB. LR-, negativelikelihood ratio; LR+, positivelikelihood ratio; n, number of participants; NB, neutrophilic bronchitis; ROC, receiver operator characteristic.

Sputum colour could be used in those who can produce a sample, either spontaneously or with a sputum induction, eliminating the need for further processing. More investigations are required to ascertain the utility of this approach to determine if sputum colour can guide treatment decisions and/or determine treatment response in clinical practice. It is also important to assess other aspects of the test performance such as clinician and patient agreement and reproducibility.

There was a positive association between a high sputum colour score $(\geq 3)$ and elevated concentration of CXCL-8 (a neutrophilic chemoattractant), total cell count (sputum cellularity) and neutrophilia (neutrophil proportion and number). A positive correlation between sputum colour score and CXCL-8 has been demonstrated in other neutrophilic airway diseases including cystic bronchiectasis ${ }^{12}$ and COPD. ${ }^{32}$ The current study emphasises the relationship between visual measure (colour score) and the inflammatory cell counts and airway mediators in identifying neutrophilic inflammation in asthma. Further, an optimal sputum colour score cut-off of $\geq 3$ may be clinically helpful in identifying patients with a high chance of having intense cellular sputum and predominant neutrophilia. This subset of patients with high likelihood of bacterial presence may be worthy of consideration to initiate an antibiotic therapy such as add-on azithromycin. ${ }^{33}$

Purulent sputum is associated with the presence of pathogens, especially bacteria. ${ }^{34} 35$ Studies of smokers with chronic bronchitis have shown that purulent yellow or green sputum (sputum colour score $\geq 3$ ) is associated with intense neutrophilia and possible bacterial presence. ${ }^{1620}$ The change to a darker colour of sputum is clinically detectable both during stable and exacerbated states. This study also demonstrated that in stable asthma, purulent sputum (score $\geq 3$ ) represented significantly higher proportions of neutrophils and sputum cultures that were positive for the presence of pathogenic microbes along with elevated concentration of CXCL-8 $(\mathrm{p}<0.001)$.

One of the limitations associated with this study was the requirement of a sputum sample and this would be difficult for some patients in the absence of a sputum induction. Second, the cross-sectional design of this study limited information collection from the 
same participant over a period of time (longitudinal changes) thus restricting determination of any causeand-effect relationships. For example, this study examined sputum colour at a single time point, thereby providing no information about the changes in sputum colour with response to therapeutic intervention. A few studies have investigated the interobserver and intraobserver variabilities of sputum colour in patients with $\mathrm{COPD}^{12}{ }^{36}$ and bronchiectasis ${ }^{14}$ and observed a variation of one point colour, thereby highlighting the effect of observer variability on reproducibility and reliability of results. Thus, our study requires further work so as to take into account the intraobserver and interobserver clinical as well as technical agreement, which can potentially influence the results and challenge the reliability and validity of this tool in both clinic and research settings.

It is unclear if airway neutrophilia truly reflects the severity of asthma or it is a consequence of other conditions such as an abnormal innate immune response, ${ }^{737}$ systemic inflammation, ${ }^{38}$ high doses of corticosteroids used to maintain asthma control, ${ }^{39}{ }^{40}$ ageing, ${ }^{22}$ diet $^{41}$ or exposure to various insults such as smoking, ${ }^{42}$ atmospheric pollutants, ${ }^{43}$ pathogen persistence or an altered microbiome. ${ }^{84}$ Participants with $\mathrm{NB}$ are likely to be non-responders to conventional treatment. ${ }^{21} 45$ Furthermore, high corticosteroid dose and poor ventilation of the lungs in these patients may contribute to the growth and persistence of pathogenic species thereby predisposing these patients to a high risk of exacerbations. ${ }^{46} \mathrm{We}$ speculate that use of sputum colour may be able to identify an important patient subgroup with chronic bacterial presence, severe airflow obstruction and refractory disease similar to that observed in the US Severe Asthma Research Program cohort. ${ }^{47}$

\section{CONCLUSION}

This pooled retrospective analysis of clinical studies in adults with stable asthma showed sputum colour to be a predictor of underlying airway neutrophilic inflammation (as assessed by CXCL- 8 concentration, total cell number and neutrophil number and proportion). The strongest associations between sputum colour and the investigated parameters (CXCL-8, total and differential cell counts and bacterial presence) was found with darker sputum (colour range including yellow to green; sputum colour score including 3-5), thereby identifying a cut-off colour score of $\geq 3$, which may be of clinical relevance.

Sputum colour may assist with the identification of neutrophilic inflammation and bronchitis and assist with clinical decision making to assess the presence of intense sputum cellularity, neutrophilic inflammation and pathogenic microbes in asthma.

Acknowledgements The authors would like to thank the clinical and lab team based at Level 2 West, Priority Research Centre for Healthy Lungs, Hunter Medical Research Institute for their assistance in collecting and processing of sputum samples.
Contributors PG and JLS: study conception/design. PG, AJL, LGW, KJB and JLS: data acquisition. KP, AJL and JLS: data analysis/interpretation. KP, PG and JLS: manuscript drafting. KP, PG, AJL, LGW, KJB and JLS: critical manuscript revision. KP, PG, AJL, LG, KJB and JLS: final manuscript approval.

Funding The grant support was offered by National Health and Medical Research Council (NHMRC), Australia.

Competing interests None declared.

Patient consent Obtained.

Ethics approval The Hunter Area Health Service and University of Newcastle Research Ethics Committees.

Provenance and peer review Not commissioned; externally peer reviewed.

Open Access This is an Open Access article distributed in accordance with the Creative Commons Attribution Non Commercial (CC BY-NC 4.0) license, which permits others to distribute, remix, adapt, build upon this work non-commercially, and license their derivative works on different terms, provided the original work is properly cited and the use is non-commercial. See: http://creativecommons.org/ licenses/by-nc/4.0/

(c) Article author(s) (or their employer(s) unless otherwise stated in the text of the article) 2017. All rights reserved. No commercial use is permitted unless otherwise expressly granted.

\section{REFERENCES}

1. Bateman ED, Hurd SS, Barnes PJ, et al. Global strategy for asthma management and prevention: GINA executive summary. Eur Respir J 2008;31:143-78.

2 Gibson PG, Wlodarczyk JW, Hensley MJ, et al. Epidemiological association of airway inflammation with asthma symptoms and airway hyperresponsiveness in childhood. Am J Respir Crit Care Med 1998;158:36-41.

3 Wenzel SE, Schwartz LB, Langmack EL, et al. Evidence that severe asthma can be divided pathologically into two inflammatory subtypes with distinct physiologic and clinical characteristics. Am J Respir Crit Care Med 1999;160:1001-8.

4 Simpson JL, Scott R, Boyle MJ, et al. Inflammatory subtypes in asthma: assessment and identification using induced sputum. Respirology 2006;11:54-61.

5 Berry MA, Shaw DE, Green RH, et al. The use of exhaled nitric oxide concentration to identify eosinophilic airway inflammation: an observational study in adults with asthma. Clin Exp Allergy 2005;35:1175-9.

6 Silkoff PE, Lent AM, Busacker AA, et al. Exhaled nitric oxide identifies the persistent eosinophilic phenotype in severe refractory asthma. J Allergy Clin Immunol 2005;116:1249-55.

7 Simpson JL, Grissell TV, Douwes J, et al. Innate immune activation in neutrophilic asthma and bronchiectasis. Thorax 2007;62:211-8.

8 Wood LG, Simpson JL, Hansbro PM, et al. Potentially pathogenic bacteria cultured from the sputum of stable asthmatics are associated with increased 8-isoprostane and airway neutrophilia. Free Radic Res 2010;44:146-54.

9 Green $\mathrm{RH}$, Brightling CE, Woltmann G, et al. Analysis of induced sputum in adults with asthma: identification of subgroup with isolated sputum neutrophilia and poor response to inhaled corticosteroids. Thorax 2002;57:875-9.

10 Wenzel SE. Asthma: defining of the persistent adult phenotypes. Lancet 2006;368:804-13.

11 Anthonisen NR, Manfreda J, Warren CP, et al. Antibiotic therapy in exacerbations of chronic obstructive pulmonary disease. Ann Intern Med 1987;106:196-204.

12 Stockley RA, Bayley D, Hill SL, et al. Assessment of airway neutrophils by sputum colour: correlation with airways inflammation. Thorax 2001;56:366-72.

13 Murray MP, Pentland JL, Turnbull K, et al. Sputum colour: a useful clinical tool in non-cystic fibrosis bronchiectasis. Eur Respir $J$ 2009;34:361-4

14 Goeminne PC, Vandooren J, Moelants EA, et al. The Sputum Colour Chart as a predictor of lung inflammation, proteolysis and damage in non-cystic fibrosis bronchiectasis: a case-control analysis. Respirology 2014;19:203-10.

15 Elmes PC, Dutton AA, Fletcher CM. Sputum examination and the investigation of chronic bronchitis. Lancet 1959;1:1241-4.

16 Miravitlles M, Kruesmann F, Haverstock D, et al. Sputum colour and bacteria in chronic bronchitis exacerbations: a pooled analysis. Eur Respir J 2012;39:1354-60. 
17 Allegra L, Blasi F, Diano P, et al. Sputum color as a marker of acute bacterial exacerbations of chronic obstructive pulmonary disease. Respir Med 2005:99:742-7.

18 Brusse-Keizer MG, Grotenhuis AJ, Kerstjens HA, et al. Relation of sputum colour to bacterial load in acute exacerbations of COPD. Respir Med 2009;103:601-6.

19 Johnson AL, Hampson DF, Hampson NB. Sputum color: potential implications for clinical practice. Respir Care 2008;53:450-4.

20 Berlyne GS, Efthimiadis A, Hussack P, et al. Sputum in asthma: color versus cell counts. J Allergy Clin Immunol 2000;105:182-3.

21 D'silva L, Hassan N, Wang HY, et al. Heterogeneity of bronchitis in airway diseases in tertiary care clinical practice. Can Respir $J$ 2011;18:144-8.

22 Brooks CR, Gibson PG, Douwes J, et al. Relationship between airway neutrophilia and ageing in asthmatics and non-asthmatics. Respirology 2013;18:857-65.

23 Belda J, Leigh R, Parameswaran K, et al. Induced sputum cell counts in healthy adults. Am J Respir Crit Care Med 2000;161:475-8.

24 Simpson JL, Powell H, Boyle MJ, et al. Clarithromycin targets neutrophilic airway inflammation in refractory asthma. Am J Respir Crit Care Med 2008;177:148-55.

25 Anon. Standards for the diagnosis and care of patients with chronic obstructive pulmonary disease (COPD) and asthma. Am Rev Respir Dis 1987;136:225-44.

26 Pin I, Gibson PG, Kolendowicz R, et al. Use of induced sputum cell counts to investigate airway inflammation in asthma. Thorax 1992;47:25-9.

27 Simpson JL, Scott RJ, Boyle MJ, et al. Differential proteolytic enzyme activity in eosinophilic and neutrophilic asthma. Am J Respir Crit Care Med 2005;172:559-65.

28 Simpson JL, Baines KJ, Ryan N, et al. Neutrophilic asthma is characterised by increased rhinosinusitis with sleep disturbance and GERD. Asian Pac J Allergy Immunol 2014;32:66

29 Stockley RA, O'Brien C, Pye A, et al. Relationship of sputum color to nature and outpatient management of acute exacerbations of COPD. Chest 2000:117:1638-45

30 Leung KP, Goren MB. Uptake and utilization of human polymorphonuclear leukocyte granule myeloperoxidase by mouse peritoneal macrophages. Cell Tissue Res 1989;257:653-6.

31 Odobasic D, Kitching AR, Holdsworth SR. Neutrophil-mediated regulation of innate and adaptive immunity: the role of myeloperoxidase. J Immunol Res 2016;2016:1-11.

32 Beeh KM, Kornmann O, Buhl R, et al. Neutrophil chemotactic activity of sputum from patients with COPD: role of interleukin 8 and leukotriene B4. Chest 2003;123:1240-7.

33 Gibson PG, Yang IA, Upham JW, et al. Effect of azithromycin on asthma exacerbations and quality of life in adults with persistent uncontrolled asthma (AMAZES): a randomised, double-blind, placebo-controlled trial. Lancet 2017;390:659-68.

34 Sethi S, Maloney J, Grove L, et al. Airway inflammation and bronchial bacterial colonization in chronic obstructive pulmonary disease. Am J Respir Crit Care Med 2006;173:991-8.

35 van der Valk P, Monninkhof E, van der Palen J, et al. Clinical predictors of bacterial involvement in exacerbations of chronic obstructive pulmonary disease. Clin Infect Dis 2004;39:980-6.

36 Reychler G, Andre E, Couturiaux L, et al. Reproducibility of the Sputum Color Evaluation Depends on the Category of Caregivers. Respir Care 2016;61:936-42.

37 Simpson JL, Phipps S, Baines KJ, et al. Elevated expression of the NLRP3 inflammasome in neutrophilic asthma. Eur Respir $J$ 2014;43:1067-76.

$38 \mathrm{Fu} \mathrm{JJ}$, Baines KJ, Wood LG, et al. Systemic inflammation is associated with differential gene expression and airway neutrophilia in asthma. OMICS 2013;17:187-99.

39 Wenzel SE, Szefler SJ, Leung DY, et al. Bronchoscopic evaluation of severe asthma. Persistent inflammation associated with high dose glucocorticoids. Am J Respir Crit Care Med 1997;156:737-43.

40 Cowan DC, Cowan JO, Palmay R, et al. Effects of steroid therapy on inflammatory cell subtypes in asthma. Thorax 2010;65:126722:384-90

41 Wood LG, Garg ML, Gibson PG. A high-fat challenge increases airway inflammation and impairs bronchodilator recovery in asthma. J Allergy Clin Immunol 2011;127:1133-40.

42 Thomson NC, Chaudhuri R, Heaney LG, et al. Clinical outcomes and inflammatory biomarkers in current smokers and exsmokers with severe asthma. J Allergy Clin Immunol 2013;131:1008-16.

43 Wallace J, Nair P, Kanaroglou P. Atmospheric remote sensing to detect effects of temperature inversions on sputum cell counts in airway diseases. Environ Res 2010;110:624-32.

44 Simpson JL, Daly J, Baines KJ, et al. Airway dysbiosis: Haemophilus influenzae and Tropheryma in poorly controlled asthma. Eur Respir J 2016:47:792-800.

45 Haldar P, Pavord ID. Noneosinophilic asthma: a distinct clinical and pathologic phenotype. J Allergy Clin Immunol 2007;119:1043-52.

46 Cox C, Kjarsgaard M, Surette MG, et al. A multidimensional approach to the management of severe asthma: Inflammometry, molecular microbiology and bronchial thermoplasty. Can Respir $J$ 2015;22:221-4

47 Moore WC, Bleecker ER, Curran-Everett D, et al. Characterization of the severe asthma phenotype by the National Heart, Lung, and Blood Institute's Severe Asthma Research Program. J Allergy Clin Immunol 2007:119:405-13. 